\title{
BUDGET DEFICITS AND REDUCTIONS IN INEQUALITY FOR ECONOMIC PROSPERITY: A KALECKIAN ANALYSIS*
}

Malcolm Sawyer

\begin{abstract}
An analysis of fiscal policy is presented in the context of a simple Kaleckian model of growth. The positive effects of budget deficits on economic activity and on growth are shown, and the appropriate scale of budget deficit derived. Alternatives to budget deficits to secure high levels of economic activity are examined, and taxation of savings and shifts in the distribution of income are seen as policies to be used alongside budget deficits.
\end{abstract}

\section{Keywords}

Fiscal policy, budget deficits, Kaleckian analysis, inequality, growth

\section{Resumen}

Se presenta un análisis de la política fiscal en el contexto de un modelo de crecimiento Kaleckiano simple. Se muestran los efectos positivos del déficit presupuestario en la actividad económica y el crecimiento, y la escala apropiada del déficit presupuestario derivado. Se examinan alternativas al déficit presupuestario para asegurar niveles altos en la actividad económica, los impuestos de los ahorros y los cambios en la distribución de renta son vistos como políticas para ser usadas durante los déficit presupuestarios.

\section{Palabras clave}

Política fiscal, déficit presupuestal, análisis Kaleckiano, inequidad, crecimiento.

* Traducción al español: Déficit presupuestarios y reducciones en inequidad para la prosperidad económica: un análisis Kaleckiano.

1 Maestría en Economía, Universidad de Londres, Profesor de Economía, Escuela de Negocios, Universidad de Leeds. Correo E: m.c.sawyer@lubs.leeds.ac.uk 


\section{Introduction}

The establishment of a sufficiently high level of aggregate demand is a necessary, but not sufficient, condition for the achievement of high rates of employment and approaching full employment. One of the essential insights of post KeynesianKaleckian macroeconomics analysis is that the market forces which would ensure that a high level of aggregate demand is achieved are weak to non-existent. Kalecki, amongst others, saw deficient aggregate demand as a pervasive feature of capitalist economies, and he considered the possible roles of, for example, increased investment and consumer expenditure and of government expenditure and taxation as ways of securing adequate aggregate demand consistent with full employment of labour. Further, he considered and rejected the various arguments which were raised against the use of fiscal policy and budget deficits. In this paper we present a macroeconomic model which may be described as Kaleckian within which the alternative fiscal and distributional policies can be presented. The underlying argument is that the achievement of a high level of aggregate demand can be approached in a range of ways, all of which require government actions, yet all of which will face formidable political obstacles.

In considering the analysis developed in this paper, it must be clearly borne in mind that securing a high level of aggregate demand would be a necessary but not sufficient condition for securing high levels of capacity utilisation and employment. In "Political aspects of full employment" (Kalecki, 1943), Kalecki focused on the political and social obstacles to the long term achievement of full employment. Specifically the idea that the economic and political power of the working class would be strengthened by prolonged full employment, and that there would be social and political pressures would build from capitalists and others to constrain that power of the working class and to bring full employment to an end. There is also (as we have argued in Sawyer, 2001, Arestis and Sawyer, 2005), the need for a sufficient size of the capital stock in terms of its ability to support full employment of labour and the ways in which the inadequacy of the capital stock has inflationary implications. When capacity is insufficient, then a relatively high level of demand would bring firms into operating where unit costs were rising, and as a consequence prices rising relative to wages, thereby depressing real wages. Workers may seek to raise money wages to catch up with prices, but that would be offset by further price rises, thereby generating rising inflation. Although the focus of this paper is on the conditions of demand, the conditions of supply and productive capacity are also important, and there is no presumption that the productive capacity of an economy is adequate (in terms of quantity, quality and geographical distribution) to underpin the full employment of labour. 


\section{A Kaleckian macroeconomic model}

In this section, a relatively simply Kaleckian macroeconomic model is outlined which will serve as a useful model in which to explore issues related to the budget deficit and other policies and the ways in which those policies could held achieve high levels of economic activity².

We start with a savings function of the form:

$$
\frac{S}{K}=\frac{s P}{K}=s \frac{P}{Y} \frac{Y}{Y^{c}} \frac{Y^{c}}{K}=\frac{s m u}{v}
$$

This is a classical savings function whereby there are savings $(S)$ out of profits $(P)$, but with no savings out of wages. The inclusion of savings out of wages, provided that the propensity to save out of wages is less than the propensity to save out of profits, would make no essential difference to the analysis (though it would if the relative ownership of the capital stock by capitalists and workers were relevant). Actual output is $\mathrm{Y}$ and $\mathrm{Y}^{\mathrm{c}}$ is capacity output (in the sense of the physical limit), $\mathrm{K}$ a measure of the capital stock and $\mathrm{v}$ the capital-capacity output ratio, and $u=\mathrm{Y} / \mathrm{Y}^{\mathrm{c}}$ is capacity utilisation.

Investment, $I$, is modelled as dependent on the rate of capacity utilisation $u$, the profit margin expressed as profits/output and denoted by $m$ and a variable $\mu$ a range of factors which influence investment, such as the state of 'animal spirits', the impact of technological opportunities etc., and which vary over time, and as a shorthand below $\mu$ is referred to as 'animal spirits'. Savings and investment are normalised by the capital stock $K$ which provides a ready entry into growth rate (of capital stock). The rate of profit $(P / K)$ is given by $m u / v$ and hence could be viewed as influencing investment through $m$ and $u$ (cf. Bhadhuri and Marglin, 1990). A linear form of the investment function is used for convenience:

$$
\text { (2) } \frac{I}{K}=\square u+\square m+\square
$$

As a prelude to the discussion below, we denote by $u^{*}$ a socially desired rate of capacity utilisation. It is anticipated from a Kaleckian perspective that, in terms of the notation above, in general (but not always) $u<u^{*}$ and the employment rate is less than what would be considered full employment. 'A considerable proportion of capital equipment lies idle in the slump. Even on average, the degree of utilisation throughout the business cycle will be substantially below the maximum reached

2 A model of this type could be said to originate with Rowthorn (1981) with the minor difference that investment is formulated as a function of capacity utilisation and the rate of profit, followed by, for example, Dutt $(1984,1990)$, Lavoie (1995). 
during the boom. Fluctuations in the utilisation of available labour parallel those in the utilisation of equipment. Not only is there mass unemployment in the slump, but average employment throughout the cycle is considerably below the peak reached in the boom. The reserve of capital equipment and the reserve army of unemployed are typical features of capitalist economy, at least throughout a considerable part of the cycle' (Kalecki, 1971, p.139) ${ }^{3}$.

In a Kaleckian framework, the inadequacy of aggregate demand to secure high levels of capacity utilisation can be readily interpreted such that at the desired level of capacity utilisation the intention to save would exceed the intention to invest, that is:

(3) $\frac{s m u^{*}}{v}>\square u^{*}+\square m+\square$

This equation encapsulates some key features of a Kaleckian approach in that there is a tendency towards an excess of savings over investment, and where there is a lack of market forces (such as changes in prices, operation of some real balance effect) which would reconcile savings and investment at a high level of economic activity (whether that is represented by full employment, target capacity utilisation etc.). It is changes in the level of economic activity which serve to bring actual savings and investment into line with each other.

The fiscal policy stance and foreign trade are now introduced to the savings and investment behaviour. Fiscal policy is represented here by the inclusion of the term $\mathrm{d}$, the fiscal deficit relative to the capital stock, and net exports relative to the capital stock by the term $\mathrm{x}$. The condition injections $=$ leakages then becomes:

(4) $\frac{s m u^{*}}{v}=\square u+\square m+\square+d+x$

This can be also read as domestic private savings equal to domestic investment, budget deficit and capital account deficit (equal to net exports). Time sub-scripts are introduced to indicate that variables such as profit margin, 'animal spirits' vary over time. From equation (4), the rate of capacity utilisation is given by:

(5) $u(t)=\frac{(\square m(t)+\square(t)+d(t)+x(t)) v}{\operatorname{sm}(t)-\square v}$

3 Kalecki did not use term such as 'desidere'capacity utilisation, and it is clearly possible that 'reserves of capital equipment' woul be compatible with capacity utilisation at is desired level from the firms perpectives. 
The rate of growth is set by the rate of investment, and the differences between savings and investment absorbed by the budget deficit. It can be readily seen from equation (4) that the budget deficit is funded from the difference between savings and investment, and that the budget deficit 'crowds in' with its positive effect on capacity utilisation.

The growth of the capital stock (equal to $\mathrm{I} / \mathrm{K}$ ) is given by:

(6) $g_{k}(t)=\frac{\square(d(t)+x(t) v+s m(\square m+\square(t))}{s m(t)-\square v}$

In this framework it can be readily seen from eqn. (5) that a budget deficit has a positive effect on capacity utilisation. From eqn. (6), it can also be seen that the budget deficit would impact positively on the (one period) rate of growth of the capital stock. The one period rate of growth of output would be based on the growth of the capital stock and change in capacity utilisation. There would be limits, coming from the growth of the labour force and of labour productivity, on the rate of growth of output and of the capital stock which are sustainable. This is not to accept some simple 'natural rate of growth' story since the growth of supply potential would itself be dependent on the growth of demand (Sawyer, 2011). But it is to recognize that there is some upper limit on sustainable investment and growth of the capital stock.

In effect, the budget deficit is set to enable investment expenditures to come through without being held back by savings behaviour. The appropriate scale of budget deficit can be readily calculated from these equations, where appropriate means the budget deficit required to secure the target level of economic activity, and capacity utilisation $u^{*}$. Thus from eqn. (5) the appropriate budget to secure $u^{*}$ is:

$$
d=\frac{s m u^{*}}{v}-\square-\square m+\square u^{*}
$$

This is ease to write down algebraically but would be extremely difficult in practice to make precise calculations of what is required. But it does represent a general principle, namely that the budget deficit should be targeted to achieve macroeconomic objectives, here represented as a desired rate of capacity utilisation. As such it stands in contrast with the prevalent view that budgets have to be balanced. The appropriate budget deficit would depend on a wide range of factors, which are here seen to be the profit margin (and hence the distribution of income between wages and profits, 'animal spirits' which drive investment (and more generally the tendencies and pressures on investment and the savings propensity. The calculation of that budget deficit at any point in time is clearly not a straightforward exercise for even in this simple model (in which, for example, foreign trade has been ignored) knowledge of key parameters is required, yet those parameters vary over time. 
A fuller analysis of the role of fiscal policy would need to enquire into the composition of taxation and of public expenditure. The structure and level of tax rates would have effects on the savings and investment functions. The latter would need to distinguish components of public expenditure (notably public investment, but also education expenditure) which impact on the growth rate of the capital stock both directly and indirectly through the impact on private investment decisions. The relevant capital stock for growth purposes would be extended to include (at least part of) public capital (e.g. infrastructure). The growth of the productive potential of an economy would depend on both private and public investment, and public investment through its demand and capacity building effects can be an effective stimulant of private investment.

The budget deficit which is relevant for the scale of fiscal stimulus is the total budget deficit (that is primary deficit plus interest payments). A continuing budget deficit (relative to capital stock) of $d$ would then lead to the government debt (relative to the capital stock) stabilising at $\mathrm{d} / \mathrm{g}$ when $\mathrm{d}$ has been measured in real terms (that is with allowance for the depreciation of the national debt as a consequence of inflation). In the absence of appropriate fiscal policy, the Kaleckian approach would imply that the economy would languish with a low level of capacity utilisation (and general implication of substantial unemployment) and low growth rate (which is demand determined). A budget deficit of $d$ raises the growth rate by $\alpha d /(s m-\alpha v)$ (as compared with a balanced budget).

There is often objections made to budget deficits and the associated public debts in terms of the resulting 'burden on future generations'. That argument can be readily dismissed just by noting that the interest payments on government bonds are a transfer from one group (taxpayers) to another group (bondholders). But it can further be noted that a budget deficit to GDP ratio of $b$ maintained would lead to a debt to GDP ratio of $D=b /(g+p)$ where $p$ is the rate of inflation and hence $g+p$ the nominal rate of growth. Writing $b=b^{\prime}+i D$ where $b^{\prime}$ is primary budget deficit, $i$ rate of interest on government bonds, then $b^{\prime}=D(g+p-i)$, and when the growth rate and the interest rate (whether both in real terms or both in nominal terms) are almost equal then the primary deficit will be close to zero and the total budget deficit equal to interest payments. In other words, there is borrowing from rentiers to pay interest to rentiers.

However in terms of burdens on future generations, the implications of equations (5) and (6) is clear - the budget deficit raises investment (via effect on capacity utilisation) and the growth rate. Thus a budget deficit (in the relevant range) raises growth and future productive capacity, and acts to benefit future generations rather than being a burden on them. 


\section{Budget deficits}

From a Kaleckian-post Keynesian perspective, the budget deficit should be viewed as strongly influenced by the expenditure and other plans of the private sector. In effect the budget deficit can be viewed as endogenous and indeed something of a residual in two senses. First, whilst a government can set tax rates and its intentions for public expenditure, the resulting budget deficit arises as a result of decisions made by the private sector and the resulting level of economic activity. The government can, of course, seek to forecast what the budget deficit will be but it does not have full power over the budget deficit.

Second, the target budget deficit should be set, along the lines of 'functional finance' as suggested above where the intention is to use the budget position to secure a high level of economic activity. Lerner (1943) put the case for functional finance, which "rejects completely the traditional doctrines of 'sound finance' and the principle of trying to balance the budget over a solar year or any other arbitrary period" (p. 355). Kalecki's argument was essentially similar: a budget deficit is required to correct a deficiency of aggregate demand, and it is precisely in conditions of deficient aggregate demand that funds will be available to fund the budget deficit. To ensure a high level of economic activity, the budget deficit should be set in line with the anticipated sum of savings minus investment plus net borrowing from overseas (equal to the current account deficit) which would be forthcoming at the high level of economic activity.

A frequent objection to the use of fiscal policy is the argument that government may not be able to fund budget deficits, and hence attempts to stimulate the economy through fiscal policy and budget deficits will be frustrated. This argument is clearly wrong, since budget deficits are required because there is an excess of (ex ante) savings over investment (at desired level of income). If a budget deficit cannot be funded, that is because there is an absence of that excess of savings over investment, in which case a budget deficit would not be required. When there is an excess of savings over investment, then a budget deficit is required to absorb the excess savings, but that, of course, is precisely the situation in which the budget deficit can be funded. In turn the savings (in excess of investment) can only be realised when the government runs a budget deficit.

Fiscal policy is often viewed in terms of the determination of government expenditure and taxation as undertaken without specific regard to the state of private aggregate demand. The 'crowding out' argument after all assumes that there is something to be crowded out. That approach to fiscal policy suggests either that fiscal policy has no effect on the level of economic activity (since there is crowding out) or that there is a positive link between government expenditure (budget deficit) and the level of economic activity. The investigation of fiscal policy through the means of simulation of macroeconometric models is concerned (usually) with the question 
of what happens if government expenditure is increased, other things being equal. The results of such simulations, generally, suggest that an increase in government expenditure does have a positive effect on the level of economic activity. Indeed in the context in which these simulations are undertaken, it is somewhat surprising that positive results are obtained since such macroeconometric models generally build in a variety of ways by which there would be crowding out - the most notable one being that imposition of some form of supply-side equilibrium, and an adjustment process by which the economy moves to that supply-side equilibrium.

The evaluation of the effects of fiscal policy has to appreciate that the scale of budget deficits depends on what is happening in the private sector. It is wellknown that falls in private demand, by lowering economic activity, tends to raise budget deficits with the reduction in tax revenues. The adoption of discretionary fiscal stimulus in recessions will mean that budget deficits will further accompany reductions in economic activity. The evaluation of fiscal policy should not start from the presumption that there would otherwise be adequate effective demand in that all would agree that in the context of adequate private effective demand there is no requirement for budget deficits.

\section{Investment and income distribution}

The equations (5) and (6) can be interpreted in terms of the other ways besides budget deficits by which the desired level of capacity utilisation can be secured. For example, equation (5) could be solved for the profit margin which would be compatible with $\mathrm{u}^{*}$ and a balanced budget $(\mathrm{d}=0)$, as:

(8) $m^{*}=\frac{\left(\square u^{*}+\square+x\right) v}{s u^{*}-\square v}$

This would indicate the profit share and by deduction the wage share which would be compatible with desired capacity utilisation and zero budget deficit. It illustrates the general point that in a Kaleckian approach the distribution of income is a relevant variable for the determination of the level of economic activity. As it stands, this is a simple algebraic exercise, but is used to illustrate the point that there may be policy alternatives to budget deficits through which high levels of economic activity can be secured. The profit share changes for a variety of reasons, though in the Kaleckian approach the degrees of market power (the 'degree of monopoly') possessed by businesses are important factors. Governments may influence the extent of competition and the market power of firms. The structure of the tax system and the relative taxation of wages and profits would be further significant factors. 
In 'Three Ways to Full Employment' Kalecki (1944) envisaged three alternatives to securing a level of aggregate demand which would be consistent with full employment. These were (i) the use of budget deficits, (ii) stimulation of investment, (iii) income redistribution. These are each reflected in the equations given above where it is clear that a higher budget deficit, higher 'animal spirits' on investment and income redistribution in the form of a lower profit margin $m$ would lead to higher levels of capacity utilisation. Those equations also indicate two other possible ways of stimulating economic activity, notably a lower savings propensity and higher net exports.

We find it rather useful to draw on this framework to discuss these possibilities. The key reason for doing so is that from a Kaleckian perspective there are no significant market forces which propel the economy to high levels of capacity utilisation. Fiscal policy is one way of doing so: but if there are political and social blockages to the use of permanent budget deficits then alternative routes have to be found for otherwise the economies will languish in low levels of economic activity. It should first be noted that in the Kaleckian framework these policy options would not only have implications for capacity utilisation (and employment) but also (from equation (6) above) for the rate of growth. Further, policy options which have been adopted by many governments can find a representation in this framework - for example, policies of export promotion and import substitution have the representation of changing $\mathrm{x}$ in the equations above. This is, of course, only a representation and does not inform about the effectiveness of such policies. This discussion enables us to present alternatives to fiscal policy in striving for high levels of demand, and also to indicate the limitations of some of these policy alternatives.

\section{Investment}

Investment in the capital stock (and more broadly) has to be considered from both a component of aggregate demand perspective and also as a contributor to the development of productive potential. In respect of the latter point, it has to be stressed that for full employment of labour to be achieved, there has to be a sufficient capital stock in regard to its overall size and its distribution (across geographical areas). There are generally shortages of capital and of the capacity to underpin the full employment of labour - in effect structural unemployment. This, we would argue, is a characteristic of industrialised and non-industrialised countries, though it may be a more severe issue in non-industrialised economies. Industrialised economies though suffer from geographically concentrated high rates of unemployment (and low rates of employment) which can be identified with a lack of effective productive capacity in the geographical areas concerned to underpin high rates of employment of labour. Thus higher rates of investment which lead to the provision of a capital stock which was larger and appropriately distributed across geographically areas, combined with a higher level of aggregate demand, enable more of those seeking employment to find it. 
However, we argue here that there are some significant limits to the extent to which investment expenditure can rise, relative to GDP, as a way of stimulating aggregate demand. The first of these arise from the observation that higher rates of investment will tend to lead to rising capital-output ratios. When investment adds to the capital stock and as a result there is more productive capacity to employ labour and there is a higher level of demand to purchase more output, then the ratio of capital stock to actual output need not rise. But under other circumstances the capital-output ratio would rise, firms operate with spare capacity and the rate of profit would tend to fall. At least for many industrialised countries, there are significant limits on the stimulation of investment as a means of adding to aggregate demand. ${ }^{4}$ The share of investment in national income is $\mathrm{I} / \mathrm{Y}=(\mathrm{I} / \mathrm{K}) .(\mathrm{K} / \mathrm{Y})$ : the first term is the growth of the capital stock, which with a constant capital-output ratio would be growth of output. Hence a capital-output ratio of 4 and growth rate of 2.5 per cent yields a 10 per cent net investment to GDP ratio. The capital-output ratio has tended to be constant. But even if the capital-output ratio was rising, the rate of profit would be tending to decline, (unless profit margins and profit share are rising). With the rates of growth observed in industrialised economies over the past few decades, further rises in the investment ratio would lead to declining profit rates and under capacity utilisation (thereby dampening any rise in the investment ratio). Unless it is thought that significantly higher rates of growth can be achieved, then the limits for investment may have been reached.

The second, and rather important, consideration is that investment is clearly intended to be an addition to the capital stock and to enable further growth of output to occur, and there are clearly limits to how far and how fast growth can proceed on environmental and resource grounds. This reinforces the limits and desirability of raising investment relative to national income.

Echoing arguments advanced by Kalecki, the proper role of private investment was the provision of the means for the production of consumption goods, and not to ensure the full employment of labour. In a similar vein public investment should be undertaken where it provides socially useful output and/or where it permits those outputs to be produced. Investment is a means to an end not an end in itself. Thus, Kalecki argued, it is the stimulation of consumption rather than investment which should be used to generate sufficient effective demand for full employment.

In terms of the equations above, the argument here is that whilst policy measures which increased $\mu$ would raise capacity utilisation and growth there are substantial limits to the usefulness of such policy measures.

4 In the circumstances of depressed demand following the financial crisis and the 'great recession' at the present time (early 2011) the stimulation of investment would lead to higher demand and economic activity. The statement in the text relates to the stimulation of investment relative to the levels which applied in the decade or so prior to the financial crisis. 


\section{Savings}

It can be readily seen from equation (5) above that over a significant range, reductions in the propensity to save would tend to raise capacity utilisation. This is not a surprising result, given the nature of the savings paradox in Kaleckian and post Keynesian macroeconomics. It should be though noted here that the model above involves savings by corporations but not by households, which can be taken to reflect the dominance of savings by corporations (in the form of retained earnings) over savings by households in many industrialised countries. There is then the significant policy conclusion that lowering the savings propensity would tend to raise capacity utilisation and indeed the growth rate. In those countries where there is a tendency for savings propensity to exceed the investment propensity, reductions in the savings propensity would have beneficial effects. The structure of taxation could then be used to achieve that - for example, retained earnings more highly taxed than distributed profits, removal of tax advantages relating to savings by households. Seeking to adjust the savings propensity should be viewed as one element in aiming for macroeconomic balance and a high level of economic activity.

\section{Net exports}

The promotion of net exports, whether through export promotion, import substitution (or both through exchange rate manipulation), would, if successful, raise capacity utilisation and growth (equations 5 and 6 above). The limitations of the use of net exports as a general means of stimulating aggregate demand are straightforward - not every country can improve their net export position. For a single country there may be possibilities through exchange rate variations and through industrial and similar policies. Apart from the limited number of countries which could pursue this route (and a number who have come to mind) it could also be said that in general the scale of a swing in net exports which would be required on its own to secure high level of demand compatible with a zero budget deficit would in its own terms be relatively large. By this we mean that the reduction of budget deficit from an average of 3 per cent of GDP to zero would require a shift in net exports of the same order of magnitude.

It is well beyond the scope of this paper to explore the various policies which could be used for promoting net exports. A major point to make is the dangers of net export promotion to become 'beggar my neighbour' policies through which the overall level of global demand is not promoted, leaving no positive effects from a net export programme.

\section{Reducing inequality}

In the model above, the distribution of income is represented by the share of profits in national income. It can be expected more generally that the inequality of income distribution will also affect the level of demand in the economy, and that a 
more unequal distribution of income be accompanied by a lower level of aggregate demand. The general proposition is that a higher wage share and a less unequal distribution of income will be conducive to higher levels of aggregate demand. It would act to also lower the average propensity to save. The broad changes in the distribution of income in industrialised countries over the past three decades are well-known - a general tendency towards increases in inequality in the personal distribution of income and a shift away from wages towards profits. The general presumption would be that this leads to a higher level of savings/lower level of consumer expenditure, with detriments on the level of demand.

In many industrialised countries, the present patterns of savings behaviour are conducive to the build-up of debt as a response to 'over savings'. The household sector engages in savings into pension funds with low overall savings (as measured in national income accounts) but savings in cash terms being negative (as savings in national accounts are reckoned to include increase in equity in pension funds and pension contributions made by employees and by employers. Further, corporations make savings which are in excess of their investments, and apart from lending to government (budget deficit) and overseas the lending of savings by corporations to households involves the latter in debt accumulation. This may occur directly (e.g. companies providing finance to households to facilitate purchase of goods produced by the companies, financial corporations are included in the corporation figures) and indirectly. Hein and Truger (2011) provide similar and more extensive arguments, and give indications of elements of the trends towards inequality.

We can give a couple of possible examples to illustrate the magnitude of changes in the distribution of income which would have a significant impact. For example, if the wage share were say 5 percentage points higher, and there is a difference in the marginal propensity to consume between wages and profits of say 0.3 , then savings would be lower by 1.5 percent of GDP. A redistribution of income from the top two deciles to bottom four deciles of 10 per cent of earnings - that is 6 to 7 per cent GDP, and the marginal propensity to consume difference of 0.2 , a further 1.2 to 1.4 per cent; these two, rounded up to 3 per cent of GDP would solve much of the budget deficit problem. The shift from profits to wages in the first example would be the same order of magnitude (but in the opposite direction) as that observed in industrialised countries such as Germany over the past couple of decades. The second example similarly would amount to the reversal of the inequality changes in the UK over the past three decades.

The policy measures designed to shift the distribution of income can be easily listed, but the issues of implementation are inversely related with the ease of listing them! Significant increases in minimum wages where such exist and their introduction elsewhere, adoption of 'living wage' ordinances, structuring wage awards in the public sector to increase lower wages faster than higher wages, enhancing the power of trade unions. Making the tax system progressive through, for example, capital 
gains treated as income for tax purpose, removing caps on earnings limits for social security contributions (with no commensurate changes to social security benefits), enhanced property taxation.

\section{Concluding remarks}

Kalecki (1944) argued that sustained full employment " $m u$ st be based either on a long-run budget deficit policy or on the redistribution of income" (p. 135, emphasis added). In this paper capacity utilisation has been used as the proxy for the level of economic activity. The target rate of capacity utilisation should not be presumed to correspond to full employment, but rather is the rate of capacity utilisation which will secure the highest rate of employment in the given circumstances of overall capacity. It would be recognized (see Sawyer, 2002, Arestis and Sawyer, 2005) that securing sufficient capacity to underpin full employment is a highly relevant consideration.

The stimulation of investment and the promotion of net exports are often seen as policy measures which would help secure higher levels of economic activity. It can be readily recognized that more lively 'animal spirits' will lead to higher levels of capacity utilisation and faster growth. But, there are limits to this, arising from the tendency for faster investment to raise the capital output ratio, leading to declining profit rate. Net exports promotion may serve a single country but cannot be a universal solution.

The starting analysis of this paper is a Kaleckian one in which a deficiency of aggregate demand (relative to a high level of economic activity) and a corresponding tendency for savings to exceed investment. The market forces which would ensure a sufficient level of aggregate demand for a high level of economic activity are lacking. A range of ways in which aggregate demand could be stimulated - such as budget deficit, reduced savings - have been briefly mentioned. The overall message is that macroeconomic policy has to be broadly interpreted and used to ensure a high level of economic activity. This should not be taken to underestimate the practical and political difficulties of implementing policies to ensure high levels of economic activity. It is rather to stress that deliberate policy measures have to be taken to promote high levels of aggregate demand. Fiscal policy can be a potent weapon in that regard. However, the need for budget deficits in this respect depends on private demand, which in turn depends on propensities to consume and to invest. In this paper we have argued that full regard needs to be paid to private demand, and ways to promote private demand. And, full regard must be paid to the role of income distribution and inequality and their impact on aggregate demand. 


\section{References}

Arestis, P. and Sawyer, M. (2005), 'Aggregate demand, conflict and capacity in the inflationary process', Cambridge Journal of Economics, vol. 29, no. 6, pp. 959974

Bhaduri, A. and Marglin, S. (1990), 'Unemployment and the real wage: the economic basis for contesting political ideologies', Cambridge Journal of Economics, vol. 14 , no. 4 , pp. $375-394$

Dutt, A. K. (1984), 'Stagnation, income distribution and monopoly power', Cambridge Journal of Economics, vol. 8, no. 1, pp. 25-40

Dutt, A.K. (1990), Growth, Distribution and Uneven Development, Cambridge: Cambridge University Press

Hein, E. and Truger, A. (2011), 'Finance-dominated Capitalism in Crisis - The Case for a Keynesian New Deal at the European and the Global Level' in P. Arestis and M. Sawyer (eds.), New Economics as Mainstream Economics, Basingstoke: Palgrave Macmillan, forthcoming

Kalecki,M. (1943), 'Political aspects of full employment', Political Quarterly, vol. 14 (4), pp.322-331.

Kalecki, M. (1944), 'Three ways to full employment' in Oxford University Institute of Statistics, The economics of full employment, Oxford: Blackwell

Kalecki, M. (1971), Selected essays on the dynamics of the capitalist economy, Cambridge: Cambridge University Press.

Lavoie, M. (1995), 'The Kaleckian model of growth and distribution and its neoRicardian and neo-Marxian critiques', Cambridge Journal of Economics, vol. 19(6), pp.789-818

Lerner, A. (1943), 'Functional Finance and the Federal Debt', Social Research, 10(1), 38-51; reprinted in W. Mueller (ed.) Readings in Macroeconomics (New York: Holt, Rinehart and Winston), pp. 353-360, where page numbers refer to the reprint).

Rowthorn, R. (1981), 'Demand, real wages and economic growth', Thames Papers in Political Economy, Autumn 1981, reprinted in M. Sawyer (ed.), Post Keynesian Economics, Aldershot: Edward Elgar

Sawyer, M.(2001), 'The NAIRU, aggregate demand and investment', Metroeconomica, vol. 53, no.1, pp.66-94

Sawyer, M. (2011), 'Path dependency and the interdependences of demand and supply in macroeconomics', Intervention, forthcoming 